\title{
THE ROLE OF TEACHERS IN PREVENTING JUVENILE DELINQUENCY IN SMA NEGERI 4 SURABAYA
}

\author{
Luluk Utami Rahmat ${ }^{1}$ Arofah Hari Cahyadi ${ }^{2}$ \\ uthfia.rifqi@gmail.com ${ }^{1}$ rahmatmailfile@yahoo.co.id ${ }^{2}$
}

\begin{abstract}
This research aimed to describe and analyze critically about the role of religious teachers in overcoming juvenile delinquency students of SMA Negeri 4 Surabaya. The research was a qualitative research. The data collection conducted by conducting observation, interview and documentation. The data analysis in accordance with descriptive research conducted with induction mindset. The results showed: (1) The role of religious teachers against juvenile students is very good, because juvenile students needed the role of adults in shaping noble and good personality to avoid delinquency in big cities (2) some kind of delinquency conducted by SMA Negeri 4 Surabaya students included disobedient to parents and teachers, skipping school, and how to wear the uniform dressing less polite (3) The role of religious teachers in preventing juvenile delinquency was very important, religious teachers in preventing juvenile delinquency work together with teachers who as counseling guidance (BK) and the principal of SMA Negeri 4 Surabaya and community leaders, by doing preventive action, repressive and curative action.
\end{abstract}

Keywords: Role, Religious Teacher, Juvenile, Delinquency

\section{A. Introduction}

Juvenile delinquency is one of the old problems that always arise in the midst of society. This problem lives up and brings its own effects all the time. Juvenile delinquency as one of the social problems that is very disturbing harmony, as well as the integrity of all values and basic needs of human life. In fact, Juvenile delinquency undermines moral values, the noble values of religion, and the various key aspects that contains.

The changing times have changed the lifestyle of the Juveniles, the oldest in 
the big cities. Most Juveniles are very actively devouring media, let alone media business people view these teenagers as a lucrative target market.

For Juvenile, it is necessary for understanding, deepening, and adherence to the teachings of Islamic Education. Since Islamic religious education is an attempt made systematically by educators or by adults to students in the form of both physical and spiritual based on Islamic law to the formation of the personality according to the size of Islam. So that later they become human beings who can understand and practice the teachings of Islam and become a view of life blessed by Allah SWT. But the daily reality shows that teenagers who commit crimes are largely ignorant of Islamic norms, may even fail to fulfill religious orders. ${ }^{1}$

Crimes committed by young people, adolescents are essentially a product of the condition of society with all the social upheaval that is in it. This teenage crime is referred to as a community disease or social disease. ${ }^{2}$

Discussing Islamic Religious Education, the character who becomes the leading role in the world of education is the teacher. The world of education is the teacher, home rehabilitation protege. Deliberately the teacher attemptes to direct the energy and the mind to remove his protege from the tricks of ignorance and evil.

Teenagers are given formal coaching in the learning process. The interaction in the teaching and learning process is not merely producing positive things, but there are also unavoidable negative impacts. The negative nature of educators who occur during the learning process will negatively affect the teenagers' mental development. Similarly, the interaction of fellow students in schools is not always profitable for them, because it often happens negative habits of a negative student learners also for other students. This very complex negative condition is a realistic entity in the oldest school environment of big cities. Therefore, it is necessary for special actions and behaviors of religious teachers / educators so that the condition of the school environment can ensure the availability of a healthy environment, both physically and psychologically.

Therefore the teacher is not only required to have a standard of knowledge, skills, attitudes and religious values, but also must have a high level of trust among his students. A teacher should get the title of recognition of the skills of science and

${ }^{1}$ Sudarsono, Kenakalan Remaja, (Jakarta: PT. Rineka Cipta, 2004), cet. ke -4, 120.

${ }^{2}$ Kartini Kartono,Patologi Sosial 2 Kenakalan Remaja, (Jakarta: Rajawali Pers, 2003), cet.ke-5, 3. 
skills as well as the recognition of his good personality. In addition, teachers should be able to provide good models for students, because what the behavior of teachers can be role models of students.

It can be concluded that how important the role of a religious teacher in preventing Juvenile deliquency. Recognizing how important the role of religious teachers in preventing Juvenile deliquency, the researcher feel interested in conducting research to find out the implementation of Islamic Religious Education, the state of religious teachers and the role of religious teachers in preventing Juvenile deliquency in SMA Negeri 4 Surabaya.

\section{B. Research Methods}

In this research would be selected qualitative approach that is the research procedure that uses descriptive data in the form of written or oral words of the people and behavior observed. ${ }^{3}$

The research is to know how the role of religious teachers in preventing Juvenile deliquency in SMA Negeri 4 Surabaya the researcher uses descriptive qualitative analysis research, the author tries to reveal the phenomena that occur in the object by finding new theories.

The source of data is Library Research that searches the data by using the books in the library used to find the theoretical foundations, about the elements of this research. Field Research namely, human data sources in the form, principal, religious teachers, all staff employees which is in SMA Negeri 4 Surabaya. In this case, it is expected to provide information about how the role of religious teachers in preventing Juvenile deliquency and it also how students respond when learning in the classroom. Non-human data sources include archives of the necessary data contained in SMA Negeri 4 Surabaya.

Data Collection Techniques include

1. Observation is a data collection technique conducted by holding a systematic observation and recording of the phenomenon under study. 4

2. Interview is the data collection formed verbal submission of questions and questions raised in the interview has been prepared thoroughly, equipped with

${ }^{3}$ Lexy J. Moleong, Metodologi Penelitian Kualitatif, (Bandung: Remaja Rosda Karya), 1999,21.

${ }^{4}$ S. Nasution, Metode Research (Bandung: Bumi Aksara, 1996), 142. 
the instrument.

3. Documentation is derived from the word document, which means goods written. In carrying out the method of documentation, researchers investigate written objects such as books, magazines, documents, regulations and so on

4. Data Triangulation is a technique of checking the validity of data that utilizes something other than that data for checking purposes or as a comparison against that data. The most widely used triangulation technique is checking through other sources. ${ }^{5}$

Technique Analysis of this research using Miles and Hubermen theory which in the activity of qualitative data analysis cover three stages as follows

1. Data Reduction

Data reduction means summarizing, selecting the essentials, focusing on the important things, then searching for themes and patterns. Data reduction is intended to define the data in accordance with the issues to be studied, thus the reduced data will give more description clearly and facilitate research to conduct further data collection. ${ }^{6}$

2. Display Data (Data Presentation)

The presentation of data is directed to the data of organized reduction results arranged in a relationship pattern so that more easily understood and plan further research work. In this step the researcher tries to compile the relevant data so that the information can be concluded and have a certain meaning. The process can be done by displaying the data, making the relationship between phenomena to interpret what really happened and what needs to be followed up to achieve the research objectives. Displaying good data is an important step towards achieving a valid and valid qualitative analysis.

3. Conclusion drawing / verification

This technique aims to present a systematic, factual, and accurate description of the facts, sifatserta relationship of the phenomenon under investigation ${ }^{7}$

By confirming the meaning of each data obtained using one or more ways, the researcher is expected to obtain information that can be used to

\footnotetext{
${ }^{5}$ Lexy J Moeleong, MetodologiPenelitianKualitatif,(Bandung:PT.Remaja Rosdakarya,2009),178 ${ }^{6}$ Sugiono,Memahami Penelitian Kualitatif,(Bandung,CV Alfabeta,2005),249.

${ }^{7}$ Sugiono, $250-251$
} 
support the achievement of research objectives. The conclusion can be followed by the evidence obtained when the field research. Verification is the determination of the final data and the whole process of the stages of the analysis so that the whole issue of the role of religious teachers in preventing Juvenile Delinquency can be answered in accordance with the data category.

\section{Results and Discussion}

\section{Religious Teacher}

In Islamic education, education is often called mu'alim, while other terms commonly used or used for education are teachers, the term is used in the formal education environment. ${ }^{8}$

Understanding the teacher is the person responsible for educating. Means the teacher is the person responsible for the development of students with all potential of the students both in terms of affective, cognitive and psychomotor. This potential must be developed in a balanced way to the highest level possible according to religious teachings. ${ }^{9}$ The teacher is the first person after the parent who can influence the personality of the teenagers, if the behavior of the teacher is not good, then generally morality will be damaged by students ${ }^{10}$. And easily fall into misbehavior, because teenagers will be easily influenced by being admired or otherwise the child can be anxious and disturbed his soul because he found a different example with the example that had been found in his house.

From the above understanding, religious teachers are personal coaching, attitudes and life views of the students. Because every religious teacher should try to equip himself with all the requirements as teachers, educators and mentors of the future of students. ${ }^{11}$

Thus the notion of religious teachers who not only fill the science of religion to high school students, but also religious teachers participate in fostering morals or personality teenagers who really expected by the nation, religion and parents in particular.

\footnotetext{
${ }^{8}$ Muhaimin \& Abd. Mujib, Pemikir Pendidikan Islam, (Bandung: Trigendi Karya, 1993), 167.

${ }^{9}$ Ahmad Tafsir, Ilmu Pendidikan Dalam Perspektif Islam, (Bandung: Remaja Rosda Karya, 1994), 74.

${ }^{10}$ Zakiyah Daradjat, Kepribadian Guru, (Jakarta: Bulan Bintang, 1983), 18.

${ }^{11}$ Zakiyah Darajat, Ilmu Jiwa Agama, (Jakarta: Bulan Bintang, 1970), 68.
} 
The requirements of religious teachers are as stated in the Law of the Republic of Indonesia regarding educator no.2 of 1989 namely the national education system described as follows:

Teachers are special educators who are appointed and assigned the main teaching, which is at the level of primary, secondary and college education. To be appointed as teaching staff and educators should be faithful and pious to God Almighty, insightful pancasila \& UUD 45 and have qualifications as teaching staff. $^{12}$

However, these conditions must be supplemented with other requirements, as stipulated by the Director of Religious Education namely:

a. Having personal Mukmin, Muslim and Muhsin

b. Obedient to practice the teachings of Islam.

c. Having the soul of educator and a sense of affection to his protégé and sincere soul

d. Know the basics of science on teacher training, especially didactic and methodical.

e. Mastering the science of religion

f. Has no spiritual flaw in him. ${ }^{13}$

These are the conditions that a religious teacher has. Therefore, we know that as a professional educator and empirically has volunteered to accept and bear the responsibility of educators who parent on the shoulders of parents. They leave it to the school, which means they delegate it as a responsibility to the teachers of religion and teachers in general, so in this case it has been shown that parents do not carelessly appoint people to educate or become teachers.

As for the characteristics of religious teachers, according to Zuhairini that the qualities that a religious teacher must possess are:

a. The teacher is friendly and always willing to understand and understand each child he faces.

b. Be patient and helpful to students and can create peace in students' psyche.

c. Firm and fair in action

${ }^{12}$ MPR, RI, UU RI No.21, Tahun 1989, Tentang Sistem Pendidikan Agama Islam Nasional (Semarang: Aneka Ilmu, 1989), 12.

${ }^{13}$ Zuahairini, Metodik Khusus Pendidikan Agama,(Surabaya,Usaha Nasional,Proyek BPTA,1980), ,36. 
d. Has a sophisticated nature and shows interesting behavior.

e. Have a unanimous knowledge so that they believe in the ability of the teacher. ${ }^{14}$

These are the traits proposed by Zuhairini in order tobe used as a guide for religious teachers in performing their duties, because in carrying out their duties religious teachers should be able to take sympathy from students faced so easy in inculcating the teachings of Islam, without any sympathy from the students it will have difficulty in educating the religion in the souls of teenagers.

The task and role of religious teachers is as educators who not only act as a mover of religious knowledge, but also the transfer of Islamic religion in the soul of adolescent students. This is also a religious teacher as a carrier of science and personality formers adolescent sisw as well as a role model protégé of his students.

The duty of religious teachers is not easy, as we imagine or think. In this case educators play a very important role in the educational process, and it is not suspected that the emphasis of wisdom, the focus of responsibility lies on the teachers of religion, because the future of adolescent students depends on smart, wise teachers being sincere and positive towards the lessons given and guiding the students towards the religion in accordance with the teachings for life in the future is needed.

Religious teachers as educators and youth coaches should be good examples both in school and in the school environment. The teacher must always be aware of his position for 24 hours a day. ${ }^{15}$ In relation to this, his duty will reveal the role or more clearly that the task he performs will give status to a person, then on that status to reveal his role, but both are interrelated.

According to Al-Ghazali, the main task of the teacher is to perfect, cleanse, purify and bring the human heart to bertaqarrub to Allah SWT. And from the above understanding, that the task of the most important religious teachers is to instill the teachings of Islam in the learners so that it will be useful for his life someday.

The task of religious teachers according to Muhaimin in his book

${ }^{14}$ Zuahirini,Metodik Khusus Pendidikan Agama,(Surabaya,Usaha Nasional,Proyek BPTA,1980), 37.

${ }^{15}$ S. Nasution, Sosiologi Pendidikan, (Jakarta: Bumi Aksara, 1994), 91. 
(Thought of Islamic Education), namely:

a. Teachers as instructors in charge of planning the teaching program and implement the program that has been prepared and end the implementation of the assessment after the program is done.

b. Teachers as educators who direct the students at the level of maturity personality personality kamil along with the purpose of Allah SWT.

c. Teachers as leaders (managerial) who lead, self-control, protégé and related communities that concerns the direction, supervision, organizing, controlling and participation of the programs undertaken. ${ }^{16}$

A teacher here not only serves as a giver and transfer of knowledge to students, but also responsible for management, direction and planning. In addition, teachers who directly handle the world of Islamic Religious Education has a duty to guide and educate and show students correctness of the street as well as a leader in the process of teaching and learning, so as a teacher leader to guide the students so that teacher is as a key that can be determined in preparing the power of education in the future. This should be balanced with the mastery of the material, translate and describe to the students through teaching process activities.

According to Nasution that religious teachers have the following roles:

1. Communicate teaching

This role must be supported by sufficient knowledge, sufficient experience of what constitutes an element in teaching and learning.

2. Teachers as modules

If teachers themselves do not see the beauty and benefits of the subjects taught, do not expect students to show enthusiasm for the Islamic Education and teachers should be role models for their students.

3. Identification figures

This role is how the teacher is able to serve a great figure related to Islamic Religious Education or he himself becomes a worthy character in the role model. ${ }^{17}$

When viewed from the role above, the religious teacher role in the lesson

${ }^{16}$ Muhaimin dan Abd. Mujib, Pemikir Pendidikan Islam, 169

${ }^{17}$ S. Nasution, Berbagai Pendekatan Dalam Belajar, (Jakarta: Bumi Aksara, Cet.IV, 1988), 16-17 
as the delivery of religious knowledge to students also acts as educators in which teachers directly become an example for their students.

It is undeniable that, the role of participating personally determines, a doctor can be different attitude with a scholar as well as a religious teacher is not the same as his actions with an armed forces. That is the role of teachers in general and as for if specifically the role of religious teachers in schools according to Zakiyah Darajat is: Teachers as siblings who understand in his soul, religious teachers who want to be targeted emotions, who can hear and understand the complaints and suffering. The teacher who will guide in his life toward social growth. ${ }^{18}$

The above mentioned role must be played by the religious teacher well in performing his teacher's duties. This avoids the conflicts of teacher's duties so that educators may place individual interests, members of the citizen community and their own educators, between teacher's and other tasks to be placed according to their position.

Thus, between the duties and roles of religious teachers in junior high schools and religious teachers in general, where the average person perceives as the one who provides the delivery of science only in school, but in fact the task is very heavy again noble because good-bad, whether naughty or not that the students depend on religious teachers.

\section{Juvenile Delinquency}

The standard term for juvenile delinquency in the concept of psychology is juvenile delinquency. Etymologically it can be described that juvenile means child, delinquency mean delinquency. Thus, the etymological definition is a child's crime. If it involves the subject / perpetrator, then juvenile deliquency becomes meaning of a bad boy or a child of criminals. ${ }^{19}$

Dr. Fuat Hasan formulates the definition of juvenile deliquency as an anti-social act perpetrated by youth / teenagers who, when committed by an adult, are qualified as an offense. ${ }^{20}$

\footnotetext{
${ }^{18}$ Zakiyah Darajat, 72.

${ }^{19}$ Sudarsono, Kenakalan Remaja, (Jakarta: PT. Rineka Cipta, 2004), cet. ke -4, 120.

${ }^{20}$ Sudarso, Kenakalan Remaja, 11.
} 
The causes of Juvenile Delinquency according to Sigmuand frend in Sudarsono are from unhealthy development, inability to adapt and the crime of children and adolescents are mental conflicts, unfulfilled needs such as feeling safe, valued, free to show personality and so on.

According to X. A. Bonger, the cause of deviasion on the development of children and adolescents is poverty at home, social unreliability and other adverse and contradictory economic conditions.

Simanjuntak mentions the causes of juvenile delinquency as follows:

a. Internal factors:

1) Biological defects - psychic

2) The negative nature, which leads to mischievous deeds.

3) Imbalance of the fulfillment of basic needs with the desire. This creates frustration and tension

4) Weak self-control and social perception

5) Inability to adapt to environmental changes that are good and creative

6) No hobby, do not have a healthy hobby.

b. External factors:

1) Lack of love from parents and the environment

2) Inadequate Islamic Education education that behaves in accordance with the natural surroundings expected by parents, schools and communities.

3) Decreased prestige of parents, teachers and community leaders. This is closely related to the absence of identification figures.

4) Ineffective supervision of influential coaching in affective domains, conjunctions, parent, community and teacher con- flicts.

5) Less appreciation of adolescents from family, school and community environment. This is closely related to the absence of dialogue between the three environments.

6) Lack of leisure time dispenser means. This is related to the unfamiliarity of officials authorized to establish a recreational park. Often officials establish buildings in recreational areas, so that the creation of the no longer exists.

7) The ignorance of families in dealing with adolescent problems, both in terms of 
sociological, psychological, and paedagogic approaches. ${ }^{21}$

For that we need the most effective solution to overcome the cause of Juvenile Deliquency, that is by providing facilities for teenagers. In addition, the creation of a quiet, peaceful family, affection and attention to their children and guidance from religious teachers.

The deviant behavior of adolescent (juvenile / anti-social misfortune) is often a description of anti-social personality or disorder of adolescent behavior which, according to Dadang Hawari, is characterized by three or more criteria of the following symptoms:

a. Often ditching

b. Involving juvenile delinquency of children / adolescents (arrested or tried juvenile court due to his behavior)

c. Issued or suspended from school for misbehavior

d. Often run from home (run away) and spend the night outdoors.

e. Always lying

f. Repeatedly having sex, although the relationship is not familiar

g. Often drunk and abusive of narcotics and other addictive substances

h. Often stealing

i. Often damages the property of others

j. Achievements in schools that are far below the level of intelligence capabilities resulting in no rise in class

k. Often opposed to higher authorities such as against teachers or parents, against rules at home or at school, no discipline

1. Often start a fight. ${ }^{22}$

To prevent the occurrence of Juvenile delinquency it is necessary to cooperate with all parties and to supervise or control the existing youth society. With this supervision, action can be taken quickly if at any time needed.

\footnotetext{
${ }^{21}$ B. Simanjutak, Pengantar Kriminologi Patologi, Sosial, (Bandung: Tarsito, 1981), Edisi kedua, 289 290.

${ }^{22}$ Dadang Hawari, Al-Qur'an Ilmu Kedokteran Jiwa dan Kesehatan Jiwa, (Yogyakarta: PT Dana Bakti Primayasa, 1997), cet. Ke -3, 196.
} 


\section{The Role of Religious Teachers in Preventing Juvenile Delinquency}

In relation to its function as a teacher and educator and mentor, it is necessary to have various roles in the teacher self. The role of this teacher will always reflect the expected behavioral patterns in many of his interactions, both with his fellow students and with other staff. And the various activities of teaching and learning interaction can be regarded as central to its role, because it is well known or not that some of the time and attention of teachers is devoted to giving instruction and guidance to their students.

One of the duties of the religious teacher is as a guide, as we know that the teaching of religion is not intended to be known but to be lived and practiced. The experience itself requires the encouragement of its mentor, the teacher of religion and requires a high level of cuk up and awareness, thus a professional religious teacher in carrying out his duties must have sufficient knowledge and also it is required to have knowledge of the ordinances of guiding and understanding the images. description of the nature, state of attitudes, abilities and conditions of the students, religious teachers must increase the wawasn religious so broad and complete, in other words the knowledge possessed by religious teachers not only write, read and translate the Qur'an and hadith only, but equipped with the moral principles of moral faith. The more complete the knowledge of religious teachers the greater the students' trust in him.

For that knowledge gama knowledge needs to be equipped with intellectual knowledge and science of education, psychology of religion, development of soul science and psychology of children, so that religious teachers can understand the personality or attitude of the students who guided, with the provision of such knowledge. Religious teachers are expected to be more flexible and wise not favoritism and appreciate the policies shown by youth students, this is because teenagers are very sensitive to what is done by religious teachers. And religious teachers must have morals in accordance with the teachings of Islam. Among the morals of religious teachers are:
a. Love the position
b. Be fair to his fellow students
c. Be patient and calm 
d. Master must be authoritative

e. Teachers should be happy

f. The teacher must be human

g. Working with other teachers

h. Working closely with the community. ${ }^{23}$

If the teenager is entering the teenage years, then parents and teachers of religion should help each other against the adolescent students to face difficulties. In this transitional phase the teenager begins to be a little lazy, his attention fluctuates and becomes anxious about the changes that exist in him. Thus, adolescent students are at the peak of mental shock seen from these traits then to avoid adolescents from delinquency and moral crisis, then religious teachers try to keep teenagers still have good personality by giving guidance by advising and prohibiting youth students not to doing delinquency deviant, and this effort is done through teaching, guiding and training.

For more details can the researcher describe as follows:

a. Through teaching activities

In guiding adolescent children to avoid juvenile delinquency, the religious teacher tries to do the teaching activity that is to convey the science of religion or religious material with the aim that adolescents can have a wide knowledge of religion and with the science students are expected to practice and live in life, so that teenage students do not fall into delinquency that deviate and have good morals for life later in the future.

In conducting this teaching activity, teachers also use methods that are suitable to guide the personality of adolescent students are:

1. Provide understanding and advice

2. Giving exemplary

Education through exemplary is one of effective and successful educational techniques, all behavioral deeds and ways of speaking will be easily imitated and followed by students. Therefore, as an educator must provide a good example so that students easily imitate what is done by the teacher.

As for psychology, it turns out humans need the nature to imitate,

${ }^{23}$ Zakiyah Darajat, $42-43$. 
especially for teenage students, because they tend to follow the things that interest him. Therefore, religious teachers should always adorn themselves with a good personality and avoid disgraceful behavior. So, the success of religious teachers in developing the personality of the students depends on the success of religious teachers in giving examples to their students, while for religious teachers who fail in giving good examples to students, it is less attention to the students, both words, deeds and advice are considered less important, for that relationship between students and teachers must be well established so that all speech or deeds of teachers will be emulated. ${ }^{24}$

\section{Methods of Qur'ani and Nabawi}

The method of this story has some features that make it have psychological and educational impact that is perfect, neat and far-reaching with the passage of time, in addition to the story of giving birth to the warmth of feelings and facilities and activities in the soul which further motivates people to change their behavior and influence their resolve accordingly with these demands and briefings and taking lessons from him.

While remembering adolescence is a time full of spirit shaking, then with the method of this story is suitable and fitting to guide and educate teenagers, because it can be an example that is able to muffle his emotions in the soul.

a. The method of prohibition and punishment

This prohibition is a must for not doing something deed such as fighting and so on. If examples and exhortations do not work then putting the matter in the right place or the firm action is punishment, while the penalty is:

b. Viewing

Viewing is a type of learning process that motivates a person to practice certain values in realizing a commendable deed. This means that appreciation of Islamic values can lead students to use their hearts and minds in searching for the truth. Thus, students will be aware that everything that lives is a harmonious, balanced and submissive to sunnatullah, if in the process of Islamic education students can live up to these values, then the kinds of potential that exist in him can grow harmonious and balanced so that emerge the virtue of transient nature,

${ }^{24}$ Tim Dosen IAIN Sunan Ampel Malang, Dasar-Dasar Kependidikan Islam, (Surabaya: Karya Aditama, 1997), 131 
patience, justice, decency, wisdom, honesty and so on. So with the emergence of the virtue is formed the conscience of students, so that he can distinguish what is good and which is bad and able to decide which to obey or which is avoided in life together.

c. Guidance Activities

In doing this guidance, religious teachers also use methods to foster teenage personalities, namely:

a) Habituation

The actual habituation contains the experience of what is accustomed to something that is practiced, therefore the description of habituation is always one with the necessity of practicing the known good. The notion of habituation is: Educational tools, because with habituation that eventually an activity will belong to students in the future, good habituation will form a good human personality, otherwise bad refraction will form a bad personality personality as well.

b) Experience

Method of experience of Islamic values for students is more practical, because of this method students have experienced it themselves, so have the creative in facing the problem of life reality to strengthen his faith. As we know that adolescence is full of mental shock that can make teenagers violate religious values. In the absence of a religious teacher or parent who directs the adolescent student in the direction favored by God through the experience of Islamic values or teachings of Islam.

Thus, the role of religious teachers in preventing juvenile delinquency. From prevention like this is expected juvenile students (teenagers) will be spared from the collapse or mischief-violation of Islamic norms and teachings that can destroy its future.

\section{Conclusions}

Based on the results of research that the researcher do in SMA Negeri 4 Surabaya, the researcher can conclude that:

1. The role of religious teachers to juvenile students in SMA Negeri 4 Surabaya is 
very good, because in guiding and educating juvenile students.

2. Types of delinquency performed by juvenile students in SMA Negeri 4 Surabaya, classified in the form of delinquency in the form of light. The form or type of delinquency is mild, among others: (a) Disobedient to parents and teachers, (b) skipping school, (c) impolite speech and behavior (d) How to dress impolite.

3. The role of religious teachers in preventing juvenile delinquency students in SMA Negeri 4, very important role. Because in preventing juvenile delinquency religious teachers cooperate with school principals, BK teachers, and community leaders. As for actions in preventing them include: (a) Preventive Action. (b) Repressive Acts. (c) Curative action.

\section{Daftar Pustaka}

An-Nahlawi,Abdur Rahman , Prinsip-Prinsip dan Metode Pendidikan Islam, CV Diponegoro, Bandung, 2001.

Al- Zuhaili ,Muhammad , Menciptakan Remaja Dambaan Allah, Cet. Ke-1, Mizan Pustaka, Bandung, 2004

Bahri Dj Syaiful \& Asnan Zain, Strategi Belajar Mengajar, Rineka Cipta, Jakarta, 1997

Darajat ,Zakiyah, Ilmu Jiwa Agama, Bulan Bintang, Jakarta, 1970

Darajat Zakiyah, Kepribadian Guru, Bulan Bintang, Jakarta, 1983

Darajat, Zakiyah , Pengantar Ilmu Pendidikan, Graha Indonesia, Jakarta, 1982

Depdikbud, Kamus Besar Bahasa Indonesia, Balai Pustaka, Jakarta, 1989

Hawari ,Dadang,Al-Qur'an Ilmu Kedokteran Jiwa dan Kesehatan Jiwa, Cet. Ke 3, PT. Dana Bakti Prima, Yogyakarta, 1997

IAIN Sunan Ampel Surabaya, Metodik Khusus Pengajaran Agama Islam, Proyek BPTA, 1980

Kartono Kartini, Patologi Sosial 2 Kenakalan Remaja, Cet. Ke-5, Rajawali Pers, 2003

Moleong Lexy, J. , Metodologi Penelitian Kualitatif, Remaja Rosda Karya, Bandung, 2009

MPR RI, UU RI No 21, Sistem Pendidikan Agama Islam Nasional, Aneka Ilmu, 
Semarang, 1989

Muhaimin \& Abd. Mujib, Pemikir Pendidikan Islam, Trigendi Karya, Bandung, 1993

Purwanto ,M. Ngalim , Ilmu Pendidikan \& Teoritis Praktis, Remaja Rosda Karya, Bandung, 1995.

S. Nasution, Berbagi Pendekatan Dalam Belajar, Cet. IV, Bumi Aksara, Jakarta, 1988.

S. Nasution, Metode Reseach, Bumi Aksara, Bandung, 1996.

S. Nasution, Sosiologi Pendidikan, Bumi Aksara, Jakarta, 1994.

Simanjutak ,B., Pengantar Kriminologi Patologi Sosial, Tersito, Bandung, 1981.

Sudarsono, Kenakalan Remaja, PT. Rineka Cipta, cet. Ke-4, Jakarta, 1997.

Sudjana ,Nana , Dasar-Dasar Proses Belajar Mengajar, CV. Sinar Baru, Bandung, 1989.

Sugiyono , Memahami Penelitian Kualitatif ,CV Alfabeta, Bandung, 2012

Sukardi Dewa Ketut Sukardi, Bimbingan dan Penyuluhan Belajar di Sekolah, Usaha Nasional, Surabaya, 1985.

Syafaat ,H. Aat dan Sohari Saharini, Peranan Pendidikan Agama Islam Dalam Mencegah Juvenile Delinquency, Rajawali Pers, Jakarta, 2008.

Tafsir ,Ahmad, Ilmu Pendidikan Dalam Perspektif Islam, Remaja Rosda Karya, Bandung, 1994.

Zuhairini, Filsafat Pendidikan Islam, Bumi Aksara, Jakarta, 1995. 